\title{
MEDIA PEMBELAJARAN MATEMATIKA PENJUMLAHAN DAN PENGURANGAN UNTUK SISWA SLB/C
}

\author{
Oleh \\ I Kadek Dharma Laksana dan Ni Ketut Kertiasih \\ Jurusan Manajemen Informatika, FTK, UNDIKSHA
}

\begin{abstract}
ABSTRAK
Media pembelajaran matematika penjumlahan dan pengurangan untuk siswa SLB/C merupakan media yang dikembangkan untuk membantu pengajar dalam memberikan bahan ajaran kepada siswa yang masih belum mengerti tentang belajar berhitung. Adapun materi yang disajikan adalah mulai dari belajar mengenal angka, penjumlahan dan pengurangan, animasi berhitung, evaluasi, latihan berhitung, video, dan cara pemakaian media. Tahapan yang digunakan dalam pengembangan media ini yaitu analysis, desain, development, implementation, dan evalution. Pembuatan coding dan animasi menggunakan Adobe Flash CS5, Adobe Pothoshop CS5, Adobe Illustrator CS5 sebagai editor gambar dan Cool Edit Pro 2.0 sebagai perekam dan editor suara. Hasil pengembangan berupa sebuah media yang dapat digunakan dalam proses pembelajaran matematika khususnya materi penjumlahan dan pengurangan untuk siswa SLB/C.
\end{abstract}

Kata-kata kunci: Media Pembelajaran, Matematika, Siswa SLB/C, Penjumlahan, Pengurangan

\begin{abstract}
Learning media for mathematical addition and subtraction for disable students in SLB/C is a media that was developed to help teacher in giving teaching materials for students with special needs who still have less understanding in counting. The teaching materials are introduction to numbers, addition and subtraction, counting introduction in animated movie, evaluation, counting practices, videos, and the instruction to use the learning media. Phases of the media development in this work are analysis, design, development, implementation, and evaluation. The codes and animations were built using Adobe Flash CS5, Adobe Photoshop CS5, Adobe Illustrator CS5 as image editor and Cool Edit Pro 2.0 as voice recorder and editor. The result of this development was a media that can be used in learning process of the addition and subtraction in mathematics for students in SLB/C.
\end{abstract}

Keywords : Learning media, mathematical, students in SLB/C, addition, subtraction 


\section{PENDAHULUAN}

Pendidikan merupakan salah satu hal penting bagi manusia. Bentuk pendidikan bisa secara akademik atau non akademik. Pemerintah telah melakukan berbagai cara untuk meningkatkan mutu pendidikan di Indonesia. Mulai dari Program wajib belajar sembilan tahun sampai wajib belajar dua belas tahun. Namun dapat diketahui juga bahwa ada beberapa anak yang tidak mampu untuk mengikuti program pemerintah tersebut. Hal ini disebabkan oleh faktor pertumbuhan dan kemampuan dari siswa tersebut.

Melihat kejadian di atas seharusnya pemerintah tidak hanya memperhatikan siswa dengan keadaan normal saja. Tetapi juga memberikan perhatian kepada siswa yang lambat belajar seperti anak Sekolah Luar Biasa. Berbicara tentang Sekolah Luar Biasa, tidak akan lepas dari keberadaan anak luar biasa. Anak Berkebutuhan Khusus adalah anak yang memiliki grafik perkembangan yang berbeda dari anak normal dilihat dari kompetensi dasar, BSNP (2006). Kondisi cara mengajar sekarang diperlukan bantuan seperti media pembelajaran dapat dikatakan demikian karena dilihat dari pengajaran menggunakan tata bahasa yang kurang efektif. Para siswa pun lebih tertarik dengan penggunaan media yang terlihat nyata.

Berdasarkan permasalahan di atas, maka perlu dikembangkan media pembelajaran yang membahas tentang cara penjumlahan dan pengurangan untuk siswa SLB/C. Media pembelajaran berhitung ini diharapkan dapat mengatasi kelemahan-kelemahan yang ada pada media manual yang telah ada saat ini. Selain itu juga dengan adanya media dapat menampilkan bagaimana cara berhitung yang menyenangkan dengan animasi, membantu guru sebagai sarana pendukung dalam proses pembelajaran untuk anak Sekolah Luar Biasa, bagi peserta didik media pembelajaran ini dapat merangsang keinginan, pengetahuan, ketrampilan, dan daya imajinasi peserta didik dalam memahami bagaimana proses belajar yang baik, dan sebagai media pembelajaran alternatif yang memungkinkan siswa belajar di sekolah.

Penelitian ini bertujuan untuk membuat rancang bangun media pembelajaran matematika penjumlahan dan pengurangan untuk siswa SLB/C dan mengimplementasikan media pembelajaran matematika penjumlahan dan 
pengurangan untuk siswa SLB/C menggunakan Adobe Flash CS 5, Adobe Photoshop CS 5, dan Adobe Illustrator CS 5.

\section{METODE PENELITIAN}

Penelitian ini mengembangkan media pembelajaran matematika penjumlahan dan pengurangan ini menggunakan model desain pengembangan yaitu model ADDIE, yang meliputi 5 tahap pengembangan yaitu analysis, desain, development, implementation, dan evalution (Pengembangan Media Pembelajaran dalam Kertiasih, 2009).

Tahap-tahap pembuatan media pembelajaran matematika penjumlahan dan pengurangan untuk siswa SLB/C. Pertama tahap analysis adalah dilakukan pengumpulan data untuk menghasilkan media yang terkait pada karakteristik siswa. Media pembelajaran apa yang dibutuhkan oleh siswa dalam pengajaran disekolah, sehingga siswa paham dan mengerti apa yang akan ditampilkan kepada siswa.

Setelah itu tahap desain merupakan tahapan media pembelajaran dibuat untuk mempermudah pengembangan sistem dalam mendesain serta merancang naskah media yang akan dibuat. Kertiasih (2009) Dengan memperhatikan tujuan pembelajaran yang ingin dicapai dan strategi pembelajaran sehingga rancangan antarmuka dibuat sedemikian rupa sehingga memenuhi kebutuhan dalam proses pembelajaran.

Tahap selanjutnya development, tahapan ini merupakan tahap dimana pengembang membuat tampilan media dalam bentuk nyata, yang dapat digunakan dengan mudah oleh siswa bersangkutan dan juga guru pengajar. Dalam proses pembuatan media ini menggunakan Adobe Flash CS 5.

Selnjutnya tahap implementation, yang mana tahap ini adalah tahap menerapkan media pembelajaran yang telah dikembangkan apakah siswa mampu dalam memahami media yang telah dibuat. Dalam hal ini guru pengajar membantu memberikan pemahaman dalam proses pembelajaran.

Tahap terakhir adalah tahap evalution, Tahap ini adalah untuk melihat keberhasilan dari media yang dikembangkan apakah sesuai dari harapan semula. Evaluasi bertujuan untuk melakukan perbaikan terhadap media pembelajaran yang 
telah dikembangkan. Namun evaluasi juga dilakukan pada tahap-tahap sebelumnya, misalnya uji ahli untuk mengetahui kualitas desain media pembelajaran, serta konten media apakah sudah sesuai dengan tujuan pembelajaran yang ingin dicapai (Kertiasih, 2009).

Berikut dapat dilihat model pengembangan ADDIE berdasarkan tahapantahapan di atas pada Gambar 1 seperti berikut.

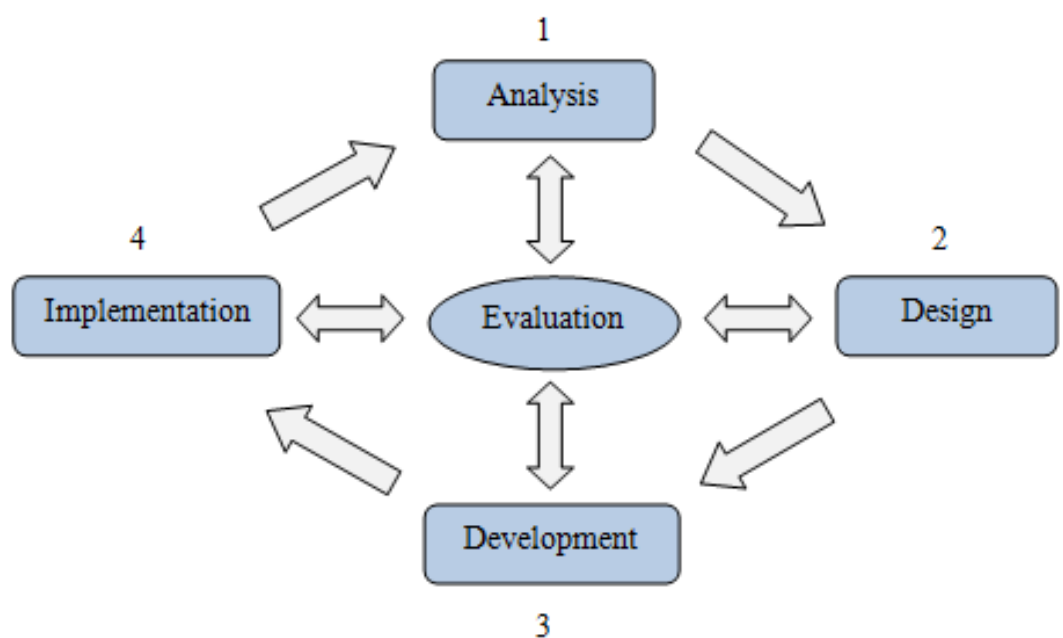

Gambar 1. Model Pengembangan Media Pembelajaran Model ADDIE

\section{HASIL PENELITIAN DAN PEMBAHASAN}

\subsection{Hasil Penelitian}

Pembangunan media pembelajaran matematika penjumlahan dan pengurangan ini, merupakan media pembelajaran yang memberikan informasi secara mudah dan menyenangkan kepada siswa tuna grahita. Selain itu dalam media ini siswa dapat belajar mengenal animasi berhitung dan memicu minat siswa untuk lebih senang belajar.

Media pembelajaran ini disajikan dengan perpaduan animasi teks dan gambar yang digunakan untuk mengimplementasikan proses-proses bagaimana cara berhitung dan mengenal angka sehingga dapat memudahkan siswa dalam mempelajari dan memahami materi yang sulit. 
Dalam media ini siswa dapat belajar dengan memilih salah satu menu yang terdapat pada tampilan utama media. Terdapat enam menu utama yaitu, menu materi, menu evaluasi, menu animasi berhitung, menu latihan berhitung, menu bantuan. Pada menu materi terdapat sub menu diantaranya menu belajar mengenal angka, pengertian penjumlahan, dan pengertian pengurangan. Pada menu evaluasi memiliki dua sub menu yaitu evaluasi latihan angka dan evaluasi latihan soal. Untuk melihat gambaran hasil implementasi media pembelajaran yang dibangun tampak pada Gambar 2 seperti berikut.

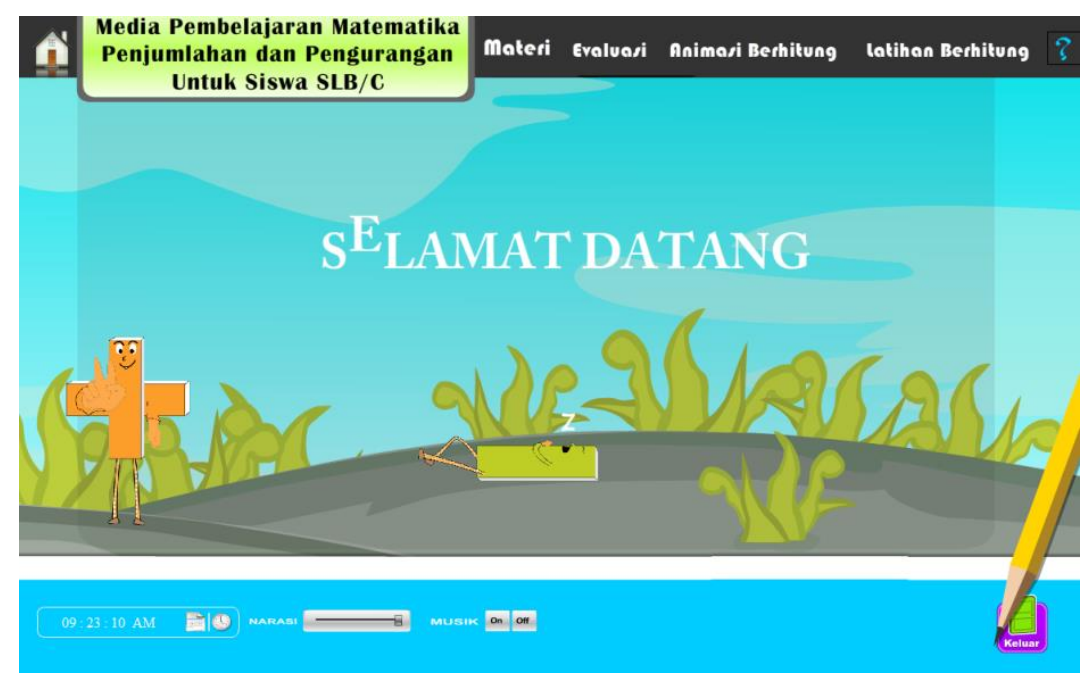

Gambar 2. Tampilan Menu Utama

\subsection{Pembahasan}

\section{A. Matematika}

Matematika adalah studi besaran, struktur, ruang, dan perubahan. Para matematikawan mencari berbagai pola, merumuskan konjektur baru, dan membangun kebenaran melalui metode deduksi yang kaku dari aksioma-aksioma dan definisi-definisi yang bersesuaian (Maswin, 2010).

\section{B. Berhitung}

Berhitung adalah proses menjumlahkan, mengurangkan, menggandakan, ataupun membagi suatu objek dan barang. Sehingga nantinya akan mendapatkan sebuah hasil. Berhitung merupakan suatu keterampilan yang membutuhkan beragam 
kemampuan seperti menyebut nama-nama angka secara berurutan, satu, dua, tiga, dan seterusnya (Rosita, 2007).

\section{Penjumlahan}

Penjumlahan adalah proses, cara, perbuatan menjumlahkan. Dapat dikatakan hasil dari menggabungkan besarnya satu bilangan dengan bilangan lain. Tanda "+" dalam penjumlahan menunjukkan bahwa bilangan-bilangan tersebut dijumlahkan" (Ian, 2011).

\section{Pengurangan}

Pengurangan merupakan operasi matematika yang mengurangkan suatu angka dengan angka lainnya sehingga menghasilkan nilai tertentu yang pasti. Simbol untuk operasi pengurangan adalah tanda minus ( - ) (Ian, 2011).

\section{E. Jenis-jenis Sekolah Luar Biasa}

Sekolah Luar Biasa merupakan sekolah yang dibangun dan diperuntukkan bagi anak-anak cacat atau anak yang tidak normal (dalam pengertian diluar kebiasaan). Di SLB terdiri dari SLB/A, SLB/B dan SLB/C. Siswa SLB/A merupakan sekolah formal khusus untuk siswa yang memiliki hambatan penglihatan/ tuna netra.

Siswa SLB/B merupakan sekolah khusus bagi siswa yang memiliki hambatan pendengaran/tuna rungu. Sekolah ini dinamakan sebagai Sekolah Luar Biasa karena dibangun dan diperuntukan bagi anak-anak cacat atau anak tidak normal. Siswa SLB/C merupakan anak yang berkebutuhan khusus (tuna grahita) autis dan debil. Tak banyak yang mengenal seputar Pendidikan Luar Biasa atau yang juga dikenal dengan sebutan Sekolah Luar Biasa. Padahal, jumlah pendidikan yang seperti ini tidak sedikit jumlahnya.

\section{F. Jenis Tuna Grahita}

Tuna grahita ringan merupakan anak yang tergolong dalam tuna grahita ringan memiliki banyak kelebihan dan kemampuan, sehingga dapat dididik dan dilatih. Misalnya, membaca, menulis, berhitung, menjahit, memasak, bahkan 
berjualan. Tuna grahita ringan lebih mudah diajak berkomunikasi. Selain itu kondisi fisik tidak begitu kelihatan secara mencolok. Anak yang tergolong ke dalam tuna grahita ringan ini mampu berlindung dari bahaya apapun. Karena itu anak tuna grahita ringan tidak memerlukan pengawasan ekstra.

Tuna grahita sedang tidak jauh berbeda dengan anak tuna grahita ringan. Anak tuna grahita sedang pun mampu diajak berkomunikasi. Namun, kelemahannya anak seperti ini tidak begitu mahir dalam menulis, membaca, dan berhitung. Tetapi, ketika ditanya siapa nama dan alamat rumahnya akan dengan jelas dijawab. Anak yang tergolong ke dalam tuna grahita sedang dapat bekerja di lapangan namun dengan sedikit pengawasan. Begitu pula dengan perlindungan diri dari bahaya. Sedikit perhatian dan pengawasan dibutuhkan untuk perkembangan mental dan sosial anak tuna grahita sedang.

Tuna grahita berat, anak tuna grahita berat disebut juga idiot. karena dalam kegiatan sehari-hari membutuhkan pengawasan, perhatian, bahkan pelayanan yang maksimal. Karena anak tersebut tidak dapat mengurus dirinya sendiri apalagi berlindung dari bahaya. Asumsi anak tuna grahita sama dengan anak Idiot tepat digunakan jika anak tuna grahita yang dimaksud tergolong dalam tuna grahita berat.

\section{G. Media Pembelajaran}

Media pembelajaran berasal dari bahasa latin yang merupakan bentuk jamak dari "medium" yang secara harifah berarti "perantara" atau "pengantar" sumber pesan dengan penerima pesan. Beberapa ahli memberikan definisi tentang media pembelajaran. Schramm dalam Sudrajat (2008) mengemukakan bahwa media pembelajaran adalah teknologi pembawa pesan yang dapat dimanfaatkan untuk keperluan pembelajaran. Sementara itu, Briggs dalam Sudrajat (2008) berpendapat bahwa media pembelajaran adalah sarana fisik untuk menyampaikan isi atau materi pembelajaran seperti : buku, film, video, dan sebagainya. Dari kedua pendapat di atas dapat disimpulkan bahwa media pembelajaran adalah segala sesuatu yang menyalurkan pesan, dapat merangsang fikiran, perasaan, dan kemauan peserta didik sehingga dapat mendorong terciptanya proses belajar pada diri peserta didik (Sudrajat, 2008). 


\section{PENUTUP}

Berdasarkan uraian pada pembahasan di atas, dapat disimpulkan bahwa media pembelajaran matematika penjumlahan dan pengurangan untuk siswa SLB/C adalah sebuah media yang interaktif dan memberikan informasi tentang berhitung pada siswa tuna grahita mulai dari mengenal angka, pengertian penjumlahan dan pengurangan, animasi berhitung, dan juga latihan berhitung dengan menggunakan animasi. Melalui media ini diharapkan dapat membantu dalam proses belajar mengajar dalam sekolah luar biasa dan meringankan beban guru pengajar, sehingga disampaikan dengan cepat dan mudah.

Berdasarkan simpulan di atas disarankan kepada pihak yang berkepentingan untuk dapat mengembangkan kekurangan media pembelajaran matematika penjumlahan dan pengurangan untuk siswa SLB/C terkait dengan materi berhitung penjumlahan dan pengurangan lebih membahas nilai yang di tambahkan menjadi nilai puluhan atau bahkan ratusan sehingga pemahaman siswa tentang materi matematika berhitung dapat berlanjut dengan baik melalui media pembelajaran ini.

\section{DAFTAR PUSTAKA}

BSNP, 2006, Standar Kompetensi dan Kompetensi Dasar, Denpasar: Departement Pendidikan Nasional

Ian, 2011, Pengertian Penjumlahan dan Pengurangan, https://ian43.wordpress.com/tag/pengertian-penjumlahan

Kertiasih, Ni Ketut, 2010, "Pengembangan Media Pembelajaran Berbasis Multimedia Gerakan Dasar Tari Bali”, JPTK, Undiksha, 6(1), 37-50.

Maswin, 2010, "Pengertian Matematika secara umum",http:/www.maswins.com /2010/06/pengertian-matematika.html, (diakses tanggal 20 Mei 2012).

Rosita, Y, 2007, “Bab II Pembelajaran Berhitung”,http://repository.upi.edu/ operator/upload/s_paud_0604392_chapter2.pdf, (diakses tanggal 25 Maret 2012).

Sudrajat, Akhmad, 2008. "Media Pembelajaran", http://www.akhmadsudrajat.com /pengertian_media.html, (diakses tanggal 15 Januari 2012). 